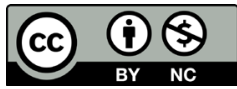

\title{
CONSTITUCIONALISMO E LITERATURA: JOSÉ DE ALENCAR E O TRIBUNAL DO JÚRI
}

\section{CONSTITUTIONALISM AND LITERATURE: JOSE DE ALENCAR AND THE COURT OF THE JURY}

Júlio Edstron Secundino Santos

Arnaldo Sampaio de Moraes Godoy

\begin{abstract}
"Nenhum estudo é tão importante para um povo livre como o da lei fundamental, fonte de seus direitos. Nos tempos de crise, quando essa lei está sujeita a ser ferida a cada instante, ela deve ser para o cidadão o objeto de constante desvelo" (JOSÉ DE ALENCAR, Uma Tese Constitucional, 1867)
\end{abstract}

\section{RESUMO}

O ensaio analisa a colaboração do reconhecido escritor José de Alencar para a discussão dos problemas constitucionais brasileiros. Alencar criticava a forma como o júri era tratado pela legislação que, a seu ver, afastava-se do comando constitucional. 0 ensaio sustenta que Alencar defendia o tribunal do júri também para matérias cíveis. Equiparava o júri ao direito de voto. Nesse sentido, o júri seria, para Alencar, legítima manifestação de soberania política.

Palavras-chave: Constitucionalismo. José de Alencar. Tribunal do Júri.

\section{ABSTRACT}

The paper analyses the efforts of a wide known Brazilian writer, José de Alencar, who also wrote on forensic subjects. Alencar criticized the way the jury trial was treated by the statutes. According to Alencar, the Brazilian statutes were far from the Constitutional commands, as regarding the trial by jury. Alencar defended the jury trial also for civil matters. For Alencar the jury was akin 
to the right of vote. In this sense, the jury trial would be, to Alencar, a legitim manifestation of the political sovereignty.

Keywords: Constitutionalism. Literature. José de Alencar. Trial by jury.

\section{INTRODUÇÃO E COLOCAÇÃO DO PROBLEMA}

As relações entre constitucionalismo e literatura sugerem muitas abordagens e padrões para discussão. Tradicionalmente, pode-se falar de uma literatura de direito constitucional, o que revela campo canônico e dogmático. Nessa primeira acepção, tem-se uma vasta produção bibliográfica de comentário e exegese. No caso brasileiro, exemplifica-se essa primeira disposição com os pais fundadores de uma literatura de direito constitucional.

É o caso dos livros de Pimenta Bueno (1857), de Soriano de Sousa (1893) e de João Barbalho Uchoa Cavalcanti (1902). Essas três obras alicerçam toda a literatura constitucional superveniente. Pimenta Bueno, o Marquês de São Vicente, é o comentador da Constituição de 1824. O capítulo relativo aos direitos dos brasileiros (2002, pp. 468-575) é ponto de partida para estudos em torno de assuntos ainda presentes no constitucionalismo contemporâneo, a exemplo de uma definição do direito de liberdade.

Soriano de Sousa, professor no Recife, onde recorrentemente discutiu com Tobias Barreto, comentou a Constituição de 1891, baseandose nos autores norte-americanos, justificando a opção porquanto a fonte de nossa primeira constituição republicana era o direito público dos Estados Unidos (1893, p. 3). Uchoa Cavalcanti comentou a Constituição de 1891, artigo por artigo, seguindo o método da tradição dos autores dos Artigos Federalistas. Ministro do Supremo Tribunal Federal, um pouco antes criado, Uchoa Cavalcanti, plasmava em seu livro o prestígio de magistrado em nossa mais alta Corte. Essa tendência se reproduz contemporaneamente, a exemplo das obras de Gilmar Ferreira Mendes e de Luiz Roberto Barroso.

Uma segunda aproximação entre constitucionalismo e literatura se desdobraria no plano discursivo, no contexto de várias teias de conexão, 
mediante um estudo sistemático da literatura aplicada ao direito (SCHWARTZ, 2006, p. 49). A estruturação dos argumentos constitucionais e, mais ainda, o modo como os juristas estruturam esses argumentos, sugerem aproximações com a sociologia literária, que inclusive passa por uma teorização do romance (LUKÁCS, 2006) e com os fundamentos da tradição retórica (GARAVELLI, 2000). A justiça, e inclusive a justiça constitucional, seria atividade de tradução, com a busca de equivalências entre realidade política e normatividade (BOYD WHITE, 1994, pp. 257 ss.). À luz dessas premissas, a Constituição revela-se como um artifício que coroa uma grande ficção, "(...) em la que descansa la superioridad de su validez normativa" (CALVO, 2016, p. 51).

Uma terceira e possível abordagem, que aqui se propõe, consiste na tentativa de se encontrar autor que seja, ao mesmo tempo, jurista e literato. Pode-se alcançar assim um ângulo estratégico de observação, que vincularia a memória constitucional com a tradição literária. Limitando-se o escopo geográfico para a tradição brasileira, registra-se que há vários escritores que eram bacharéis em direito, e que muitos exerceram a advocacia, a promotoria, a magistratura e o magistério jurídico. Entre eles, Gregório de Matos Guerra, Cláudio Manoel da Costa, Tomás Antônio Gonzaga, Gonçalves Dias, Álvares de Azevedo, Castro Alves, Raul Pompeia, Raimundo Correia, Alphonsus de Guimaraens, Augusto dos Anjos, Graça Aranha, Godofredo Rangel, Monteiro Lobato, Oswald de Andrade, Alcântara Machado, José Lins do Rego, Clarice Lispector, Jorge Amado, Lygia Fagundes Telles.

No presente ensaio explora-se o assunto no contexto da obra jurídica do escritor cearense José Martiniano de Alencar (1829-1877. Alencar é nome central da literatura ficcional brasileira do século XIX. Tratase de nosso maior prosador romântico e, provavelmente, do mais lido romancista do brasileiro (MERQUIOR, 1977, p. 79). Alencar também se destacou como eminente jurista. Foi parlamentar, foi Ministro da Justiça, e foi também advogado junto ao Conselho de Estado (MAGALHÃES JÚNIOR, s.d. pp. 121 ss.). É, nesse sentido, reconhecido como o jurista literato (LOPES, 2010). Militou na política, polemizou, inclusive com D. Pedro II. Importante biógrafo contemporâneo afirma ter sido Alencar um inimigo do rei (LIRA NETO, 2006). 
Como um jurista literato do século XIX, reconheceu e discutiu problemas de índole constitucional? Pode-se detectar alguma aproximação entre suas preocupações de escritor ficcional com autor de textos jurídicos?

No contexto dessas duas indagações o ensaio pretende sumariar a obra jurídica de José de Alencar quanto a um tema específico, o tribunal do júri, assunto que o ocupou de modo intenso. Como se observará, Alencar vinculava o conselho de jurados à realização plena da democracia, equiparando o direito ao júri como direito de voto.

\section{A OBRA JURÍDICA DE JOSÉ DE ALENCAR, LINHAS GERAIS}

Alencar ingressou na Faculdade de Direito em São Paulo, em 1846. Em 1848 transferiu-se para Olinda. Retornou para São Paulo, onde graduou-se na turma de 1850. De acordo com um memorialista da Faculdade do Largo de São Francisco, Alencar "tinha 13 anos de idade quando tomou o rumo de São Paulo, onde ficou sob os cuidados de um parente seu, então terceiro-anista de Direito (....) a república onde morou situava-se na Rua de São Bento, esquina da Rua da Quitanda"(NOGUEIRA, 1977, p. 131). Segundo esse mesmo memorialista, São Paulo contribuiu para que o talento (literário) de Alencar frutificasse; “(...) havia ele trazido, no seu baú, uma porção de cadernos escritos em letras miúdas e que outra cousa não eram senão fragmentos de romances" (NOGUERIA, 1977, pp. 131-132).

Em São Paulo, a par do direito, Alencar registrou, em relato autobiográfico publicado por seu filho, Mário de Alencar, que estudos de filosofia e de história preenchiam a maior parte de seu tempo (ALENCAR, 1893, p. 32). 0 escritor registrou essa experiência, como central em sua formação pessoal. Para o jurista literato, "os dois primeiros anos que passei em São Paulo, foram para mim de contemplação e recolhimento de espírito (...) assistia arredio ao bulício acadêmico; e familiarizava-me de parte com esse viver original, inteiramente desconhecido para mim, que nunca fora pensionista de colégio, nem havia até então deixado o regaço da família" (ALENCAR, 1893, p. 31). 
A estatura de Alencar como romancista ofuscou sua trajetória como jurista. Porém, deve-se registrar, Alencar advogou no Rio de Janeiro, no movimentado escritório de Caetano Alberto Soares. Como jornalista, coordenou a parte forense do Correio Mercantil. Lecionou Direito Comercial. Deixou-nos textos densos em matéria cível, penal e constitucional. Entre os vários assuntos que tratou, a discussão em torno do art. 144 da Constituição de 1824, relativa ao Conselho de Estado e a participação dos filhos do Imperador naquele colegiado. Alencar destacou-se, nesse caso, como fino intérprete da Constituição, aferrandose à letra do texto outorgado por D. Pedro I. Do ponto de vista ideológico, Alencar era um conservador na política. Entre outros pontos, defendeu - - em termos - - a escravidão.

Em Esboços Jurídicos (ALENCAR, 1883) o escritor cearense reúniu estudos sobre o tribunal do júri, sobre o processo criminal e sobre a codificação civil. Em A Propriedade (ALENCAR, 2004 [1883-b]) dissertou sobre tema de direito privado, com várias referências ao assunto, sob uma ótica constitucional. Quanto a tema de direito constitucional propriamente dito, Alencar explorou discussão em torno da presença da Princesa Isabel e de seu esposo no Conselho de Estado (ALENCAR, 1867).

Há também um volume de resgate histórico, relativo a seus pareceres, quando atuou como consultor no Ministério da Justiça, editado com primorosa introdução do jurista cearense Fran Martins (ALENCAR, 1960), que insistia na necessidade de que se estudasse a obra jurídica de José de Alencar ${ }^{1}$. De algum modo, é o que se pretende enfrentar nas observações que seguem. Pretende-se explorar a experiência jurídica de Alencar no tema do tribunal do júri, que é assunto de direito constitucional por excelência, qualificado no contexto dos direitos e garantias do cidadão.

\section{JOSÉ DE ALENCAR E O TRIBUNAL DO JÚRI}

Alencar radicava na Constituição a organização e o funcionamento do tribunal do júri. Copiado do modelo inglês, o júri representava fórmula democrática de julgamento. Segundo Alencar, o júri estaria para a democracia do mesmo modo que o sufrágio. A relação seria de muita 
similaridade. Alencar defendeu o tribunal do júri com veemência e forte argumentação, como se demonstrará.

0 art. 151 da Constituição de 1824 dispunha que o Poder Judicial [à época, a expressão utilizada era Judicial, nãoJudiciário] era independente, composto de juízes e jurados, que teriam lugar no cível e no crime, nos casos, e pelo modo, que os Códigos determinarem. 0 art. 152 dispunha que os jurados se pronunciariam sobre o fato e os juízes aplicariam a lei. A partir desses artigos da Constituição Alencar argumentava em favor das prerrogativas desse tribunal que reputava democrático.

Alencar observou, inicialmente, que havia duas maneiras de se violar a lei. Não se cumpre a lei quando uma ação contraria um postulado legal geral. E também não se cumpre a lei quando se omite em relação a seu efetivo cumprimento. Para Alencar, a Constituição de 1824 era recorrentemente violada e ofendida. Vários de seus princípios de grande alcance eram esquecidos ou desprezados. A indiferença para com o tribunal do júri era um exemplo desse desrespeito (ALENCAR, 1883, p. 1).

Nos termos da lei fundamental então em vigor, segundo Alencar, o Poder Judicial era composto de dois elementos distintos, mas que objetivavam a um fim comum. Aos juízes competia aplicar as leis. Aos jurados incumbia o pronunciamento sobre matéria de fato. Essa organização era prevista pela Constituição tanto para questões cíveis, quanto para questões criminais.

Escrevendo quase meio século da outorga de Constituição de 1824, Alencar se queixava de que pouco fora até então realizado para que se organizasse, efetivamente, o tribunal do júri. Entre outros problemas, queixava-se que o Código de Processo Criminal de 1832 dera um golpe profundo na Constituição, mediante a criação dos juízes municipais (1883, p. 2).

De fato, nos termos do art. 5 do Código de Processo Criminal de 1832 dispunha-se que em cada termo ou julgado, ao lado do Conselho de Jurados (o Tribunal do Júri), haveria um juiz municipal, um promotor público, um escrivão das execuções, a par de oficiais de justiça. De acordo com o art. 33 do Código de Processo Criminal, a nomeação dos Juízes Municipais se fariam listas a cada três anos, com candidatos tirados dentre os habitantes da cidade, formados em direito, ou advogados hábeis, ou 
outras quaisquer pessoas bem-conceituadas, e instruídas; e nas faltas repentinas a câmara nomearia um juiz, que serviria interinamente. Os juízes municipais substituíam os juízes de direito, nos impedimentos ou faltas, executavam as sentenças e exerciam a jurisdição criminal. Esses juízes não eram previstos pela Constituição, de onde a hostilidade de Alencar (1883, p. 2).

Ao dissertar sobre a natureza do tribunal do júri Alencar argumentava que se tratava de um tribunal de forte representatividade, protagonizando múnus constitucional que prestigiava e realizava o modelo democrático. Teorizando no campo da ciência política, e da justificação do direito, observava:

"A constituição do poder político e sua divisão é, depois da representação nacional, a questão mais culminante do governo livre. A representação nacional transmite a porção de soberania necessária para a direção do Estado; a constituição do poder limita e define a delegação, discrimina suas atribuições, e as reveste das garantias indispensáveis à independência e equilíbrio dos diversos ramos de autoridade. A fonte primeira e única de todo o poder como princípio é a democracia, a vontade da nação; mas para sua realização carece o poder de agentes que o exerçam" (ALENCAR, 1883, p. 10).

Alencar argumentou no sentido de identificar no júri, e na soberania de seus vereditos, um importante instrumento de realização do ideal democrático. Para que o Poder Judicial se realizasse efetivamente como poder independente, sustentava Alencar, o júri deveria funcionar em toda sua plenitude. Caso contrário, o Poder Judicial seria "(...) uma simples repartição do executivo" (ALENCAR, 1883, p. 13).

0 Poder Judicial era confiado à magistratura, que era nomeada pelo Governo. No sistema da Constituição de 1824 ainda não havia concurso para provimento de cargos de juízes. Além do que, juízes poderiam desempenhar várias funções. Eram removidos como juízes de paz, como promotores, como delegados de polícia. Ascendiam à presidência das províncias, tornavam-se ministros, eram nomeados para o Conselho de Estado. Não se tratava de uma carreira única e exclusiva. Para Alencar não se poderia prescindir da intervenção popular nos julgamentos, o que ocorria com o Conselho de Jurados. 0 tribunal do júri, argumentava 
Alencar, era importante elemento do sistema representativo (ALENCAR, 1883, p. 13).

Alencar insistia no tribunal do júri como esperança para julgamentos democráticos. Observava que passados 43 anos depois da outorga (Alencar denominava promulgação) da Carta de 25 de março, estavase muito longe da realidade da doutrina constitucional, que encerrava em matérias judiciais a mais bela expressão das democracias. Segundo Alencar, "a geração da independência teve uma tão pura intuição da liberdade que a atual, não obstante a superioridade de sua ilustração, ainda não pode atingir a altura da Constituição brasileira" (1883, p. 2). Alencar criticava a própria geração, que não teria realizado os ideais que marcaram o texto liberal de 1824. No entanto, não admitia a renúncia para com a esperança de que um dia se realizasse "o grande pensamento constitucional do julgamento democrático” (1883, p. 3).

As reformas do processo, ocorridas a partir da década de 1830, não conseguiram realizar a determinação constitucional para que contássemos com um tribunal do júri que funcionasse - -inclusive - para questões cíveis. Alencar denunciava que havia no silêncio e na oposição do legislador uma grave lacuna. Não teria havido, até então, uma tentativa séria de se realizar, como determinado, o mandamento constitucional. Ainda que alguns espíritos com mira na popularidade, e outros, movidos por um sentimento de lealdade à lei fundamental, tivessem se manifestado em favor do júri para questões cíveis, não se avançava de aspirações efêmeras (ALENCAR, 1883, p. 5). Alencar queria, de fato, que o júri também se organizasse para tratar de assuntos de direito civil.

Lembrava que o júri para questões cíveis era uma importação de uma ideia inglesa. Afirmava que se tratava de uma instituição nascida e educada no ambiente de um povo excepcional. Reconhecia a dificuldade para a aclimação do júri no Brasil. Além de índole diversa e da pouca instrução das classes médias, argumentava Alencar, subsistiam tradições inveteradas em um processo civil que reputava de monstruoso, ainda radicado nos juristas da tradição do direito romano que triunfava em Bolonha e em Pisa, nos séculos XV e XVI (1883, p. 6). 
Alencar argumentava também que se o preceito constitucional do tribunal do júri fosse inexequível ou nocivo, deveria ter sido revogado pelos meios competentes, isto é, por alteração legislativa (ALENCAR, 1883, p. 6). A alteração da Constituição deveria ter sido efetivada. A mera omissão comprovava, na denúncia de Alencar, forte desrespeito para com a Constituição então vigente. Essa violação era comprovada, e assim a situação se manteria, até que se organizasse o júri para o julgamento de matérias de índole civil.

Nesse sentido, Alencar indagava se o tribunal do júri seria, do ponto de vista constitucional, integrante efetivo do poder judicial. Nesse contexto, lançava uma série de perguntas, nomeadamente:

"O júri é no civil realmente prejudicial, e, portanto, inexequível o preceito da Constituição? Os males que de sua realização provenham, são maiores que o de uma reforma constitucional, ou da desmoralização da lei orgânica do país, violada com escândalo? Não há meios de corrigir os defeitos do júri, como atualmente existe, e aproveitando sua ideia substancial, adaptá-lo ao melhor julgamento de fato?" (ALENCAR, 1883, p. 7).

Alencar desafiava os argumentos que sustentavam que o tribunal do júri para causas do cível era de pouca eficiência, o que não justificaria sua implantação. Para Alencar, essa linha de raciocínio tornava inexequível a regra constitucional. Se houvesse defeitos na fórmula então vigente, argumentava Alencar, soluções deveriam ser buscadas para a correção.

Não se poderia deixar de aplicar a regra constitucional mediante o uso de argumentos de funcionalidade. Não deixava de lamentar que sua época colaborava para a decadência de uma instituição - - o júri- - que fora a primeira consequência da ideia de democracia representativa. Nesse passo, lembrava que o Decreto no 562 , de 2 de julho de 1850, retirava do tribunal do júri a competência para tratar dos crimes de imprensa (ALENCAR, 1883, p. 8). Atentava-se contra esse tribunal de feição constitucional.

0 júri teria atingido um ponto de muito descrédito no Brasil. No entender de Alencar, pretendia-se restringir o alcance de um instituto verdadeiramente democrático. Persistia o tribunal do júri, ainda que não funcionando em sua absoluta plenitude, por uma espécie de pudor 
público. Para Alencar, havia ainda um certo vexame em se trair tão abertamente a Constituição (ALENCAR, 1883, p. 8). 0 jurista literato admirava-se que o poder pretendia anular o júri e que, ao mesmo tempo, o cidadão queria esquivar-se dele (ALENCAR, 1883, p. 9).

No entanto, o júri garantia ao Poder Judicial o selo da opinião popular. Esse julgamento, por parte dos cidadãos, quanto aos fatos, seria essencial à atuação no sistema representativo. Percebe-se em Alencar forte influência dos publicistas ingleses do século XIX, a exemplo de John Stuart Mill. 0 júri, segundo Alencar, fora a “(...) primeira intuição que teve a humanidade da verdadeira democracia representativa (...) ainda a Inglaterra estava sob o jugo do feudal, e magna carta do sistema representativo não tinha sido promulgada, que o julgamento dos jurados era uma garantia do cidadão inglês" (1883, pp. 13-14).

Alencar alista-se entre os brasileiros que admiravam as instituições inglesas, dentre eles, Joaquim Nabuco. Chama a atenção o fato de que, em alguns temas, a exemplo do espinhoso assunto da escravidão, Nabuco e Alencar pensavam de maneira distinta. Nesse sentido, com o benefício do retrospecto, pode-se constatar que um mesmo modelo político e normativo era o pano de fundo e o substrato conceitual para duas visões distintas, também de problemas aparentemente distintos. Nabuco e Alencar festejavam a monarquia inglesa, que percebiam como uma experiência democrática a ser copiada. Alencar, especialmente, perseverava que a primeira forma da verdadeira democracia consistia na possibilidade de que o cidadão fosse julgado por seus pares (ALENCAR, 1883, p. 14).

O Parlamento e o júri nasceram em uma mesma pátria, a Inglaterra (ALENCAR, 1883, p. 15). Para o escritor jurista cearense essa identidade, menos do que mera coincidência histórica, consistia em emblemática comprovação de que o Tribunal do Júri era instrumento da verdadeira democracia. Dois aspectos justificavam e fundamentavam o júri, do ponto de vista procedimental. De acordo com Alencar, seguindo o mandamento constitucional, havia uma especial razão para sua adoção plena, que consistia na competência para apreciar e deliberar sobre matéria de fato. Além do que, a composição decorria de um juízo randômico, justamente porque radicava no sorteio (ALENCAR, 1883, p. 16). 
Para Alencar, a racionalidade da magistratura poderia levar a iniquidades, situação que poderia ser corrigida mediante a intervenção do júri popular. A magistratura da toga era distante para com as instabilidades da vida, especialmente no que se refere à angústia dos economicamente mais fragilizados. Além do que, circunstâncias fáticas exigiriam uma avaliação de quem tivesse uma maior proximidade com os dramas que ensejam as várias questões levadas ao judiciário. Por isso, a importância do conselho de jurados, no sentido de que, construído por um processo livre - - a sorte - - se alcançaria uma justiça mais próxima dos problemas a existência.

Alencar entendia que os três ramos do poder (judiciário, legislativo e executivo) inspirariam três fases muito distintas da ação humana. Julgamentos qualificavam atos práticos de resultado imediato. A lei decorreria de uma representação da vontade. A execução das normas decorreria de um movimento. Assim, a lei seria a vontade, o julgamento, o ato, e a execução, o movimento (ALENCAR, 1883, p. 17). 0 Tribunal do Júri realçaria o julgamento enquanto ato.

No contexto das discussões relativas à democracia participativa no século XIX, Alencar argumentava em favor do júri como indicativo de uma maioria, necessária para o alcance da justiça social. Insistia que "muitos pensam melhor do que poucos" (1883, p. 19). Questionava uma unanimidade inalcançável, que não passaria de uma "minoria mesquinha, em confronto com a humanidade civilizada" (1883, p. 19).

A justiça, especialmente quando exigida em casos concretos, demandaria um intérprete de mais amplo alcance, que qualificasse uma opinião universal. Essa opinião comum poderia ser alcançada mediante o reconhecimento das diversidades ideológicas, materiais, religiosas e circunstanciais que distinguiriam os vários jurados. 0 júri, segundo Alencar, era um instrumento de realização da democracia, especialmente na medida em que funcionando ao lado da magistratura da toga. A opinião universal qualificaria um verdadeiro intérprete da justiça. Alencar questionava como obtê-la. A solução residia no interrogatório da consciência de um certo número de pessoas, indicadas por critérios absolutamente isentos, decorrentes da escolha pela sorte (ALENCAR, 1883, p. 20). 
Alencar confrontava uma visão tradicional que abominava a utilização de qualquer forma de sorteio com vistas à obtenção da justiça. Ainda no século XVI, François Rabelais (1494-1553) fixou em sua obra um imaginário juiz que sentenciava mediante o uso dos dados. A sorte é que configurava o vencedor da demanda. Cético e irreverente, Rabelais denominava essa esquisita fórmula judiciária de Alea Judiciorum, argumentando que os contemporâneos desse juiz - - Bridoye - - entendiam que “(...) a sorte é muito boa, honesta, útil e necessária à solução dos processos e dissenções." (RABELAIS, 1991, p. 578).

0 Juiz Bridoye julgava com base na sorte porque gaudent brevitate moderni (os modernos gostam da brevidade). Rabelais explicou o procedimento, em passo espirituoso, emblemático da aproximação entre direito e literatura:

"Faço como vós, senhores, como é uso na judicatura, ao qual o nosso direito manda sempre sujeitar-nos (...). Tendo bem visto, revisto, lido, relido, passado e folheado as queixas, adiamentos, comparações, comissões, informações, antecipações, produções, alegações, contestações, réplicas, tréplicas, pareceres, despachos, interlocuções, retificações, certidões, protelações, escrituras, agravos, ressalvas, ratificações, confrontações, acareações, libelos, apostilas, cartas reais, compulsórias, declinatórias, antecipatórias, evocações, remessas, contra-remessas, baixas, confissões, suspensões, prosseguimentos, e outros incidentes, provocados por uma ou outra parte (...), coloco na extremidade do gabinete toda a papelada do réu e tiro-lhe a sorte (...). Isso feito, coloco a papelada do autor (...) na outra extremidade da mesa (...). E então uso os meus dadinhos (...). Tenho outros dados bem bonitos e harmoniosos, os quais uso, (...). quando a matéria é mais clara, quer dizer: quando a papelada é menor". (RABELAIS, 1991, p. 578).

Bem entendido, o uso da sorte prescrito por Alencar diferenciavase do modelo criticado por Rabelais. Alencar pretendia compor um conselho de jurados mediante sorteio. 0 cético francês gracejava de um juiz que julgava sem levar em conta os dados e circunstâncias do processo. Os dados, como utilizados pelo juiz Bridoye, apenas acelerariam o julgamento. Não há assim, qualquer semelhança entre as duas fórmulas.

A escolha do jurado mediante sorteio, prosseguia Alencar, era um modo de embaralhar todas as opiniões (ALENCAR, 1883, p. 20). As classes sociais seriam mescladas porque os jurados seriam recrutados de todos 
os grupos sociais. Esse método alcançaria um perfil geral de cidadão. De tal modo, esse grupo, os jurados, representariam uma opinião universal. Segundo o jurista literato,

"O verdadeiro intérprete da justiça é a opinião universal; e como esta não se revela por si, de uma maneira positiva, e sobre todos os fatos submetidos a julgamento, o meio de obtê-la, não pode ser outro, senão, interrogar a consciência de um certo número de homens, a qual, desprendida de quaisquer considerações políticas, resuma, ou antes, reflita a consciência da humanidade". (ALENCAR, 1883, p. 20).

No passo seguinte, Alencar fixou o que denominou de princípios cardeais do júri (1883, p. 21). Seus membros devem ser designados por sorteio. Esse método alcançaria o maior conjunto de possibilidades de uma representação ideal do meio social. Haveria, assim, o rompimento de todas as formas de solidariedade de interesses e de afinidades em uma determinada localidade. 0 conselho do júri formado por sorteio atuaria como uma fórmula de pretensão a qualquer perigo de suspeição ou impedimento, ainda que, naturalmente, sujeito ao resultado do próprio sorteio. Nesse último caso, tinha-se o risco de uma situação que não se poderia de antemão controlar.

O sorteio alcançaria uma base larga de representação. Refletiria uma consciência geral, afastando prejuízos e malefícios de uma consciência única de classe ou de situação, o que recorrente na magistratura de toga, egressa da classe dominante. No século XIX não se conhecia a organização da magistratura como se conhece contemporaneamente. Os juízes eram todos indicados pelas forças políticas. Como já indicamos no início, não havia uma carreira única. Magistrados transitavam em vários cargos. Atuavam como promotores, juízes de paz, delegados de polícia, presidentes de província. Vários nomes da reminiscência jurídica brasileira do século XIX protagonizaram essas várias funções, a exemplo de Zacarias de Góes e Vasconcelos, Pimenta Bueno, Nabuco de Araújo, entre tantos outros.

Havia ainda o Conselho de Estado, o cérebro da monarquia, na expressão de Joaquim Nabuco (CARVALHO, 2003, p. 357). O Conselho de Estado reunia juristas e políticos que debatiam grandes problemas 
nacionais, a exemplo da escravidão e da política externa, na medida em que consultados pelo Imperador, aviando soluções, que pelo Monarca eram (ou não) aprovadas. Alencar participou ativamente do Conselho, como advogado. Entre seus pares, vários juristas que haviam exercido a magistratura. Entre eles havia uma comunhão de interesses de classe dominante, ainda que divididos por intrigas de pormenor, que os seccionavam em liberais e conservadores.

Resumidamente, Alencar indicava os três pontos que justificavam a escolha do júri, inclusive para matérias do cível:

"I- Designação dos membros do tribunal por meio da sorte; que rompe todas as solidariedades de interesse e afinidades de ideias entre os cidadãos de uma localidade;

II- Uma base larga, a fim de abranger todos os elementos da sociedade, de modo que seja a consciência pública, e não a consciência de classe, quem julgue;

III- Um número de jurados bastante, para se presumir que ele resume em seu seio as diferentes impressões e a vária fisionomia da sociedade". (ALENCAR, 1883, p. 21).

Havia, no entanto, um grave perigo, que Alencar alertava. Pretendiase fixar como condição para indicação de jurados as mesmas condições impostas ao exercício do voto. No século XIX conhecia-se, no contexto da Constituição de 1824, art. 92, o denominado voto censitário. Eram excluídos do processo os menores de 25 anos, com exceção de casados e oficiais militares maiores de 21 anos, bem como os bacharéis formados e os clérigos de ordens sacras.

Também eram excluídos do direito de voto - e, por consequência, do júri- os filhos menores, que vivessem com os pais, exceto se exercessem cargos públicos. Criados de servir, administradores de fazendas e de fábricas, religiosos que vivessem em comunidades claustrais também não tinham direito ao voto e a pertencerem ao conselho de jurados. E, principalmente, não tinham direito ao voto e ao conselho de jurados os que não tivessem renda anual expressiva, calculada por bens de raiz, indústria, comércio ou emprego. 
Equiparar-se o direito ao conselho de jurados ao direito de voto, segundo Alencar, seria a destruição das bases conceituais do sistema. O núcleo do argumento de Alencar consistia em equiparar o direito de voto ao direito de ser julgado pelos pares. Porém, a equiparação entre o voto e a composição do júri revelava um obstáculo que impedia o pleno funcionamento do júri, como disposto, segundo Alencar, pela própria Constituição. Isto é, o uso do censo para a composição do júri excluiria a classe trabalhadora e as pessoas mais pobres. Não se poderia exigir do jurado as mesmas condições exigidas para o eleitorado. A comprovação de renda sufocaria o modelo do júri.

Chama a atenção um ponto não levantado por Alencar. Referimonos à participação feminina. Às mulheres era impedido a participação do júri, especialmente se levarmos em conta as condições eleitorais como condições prévias para participação no conselho de jurados. A literatura jurídica do século XIX tinha por certo e perfeitamente normal essa exclusão. De tal modo, o problema não era objeto de consideração. Com a aplicação das condições eleitorais para o exercício do múnus no conselho de jurados obtinha-se, segundo Alencar, uma inversão do caráter do tribunal do júri. 0 que era um direito passou a ser um ônus (ALENCAR, 1883, p. 21). Na literatura de ficção, Alencar fixou esse problema no romance Senhora, no qual Aurélia, personagem central, não poderia passar de um grande e compassivo coração e, portanto, excluída do processo decisório (DEL PRIORE, 2013, p. 63).

Alencar apontou também um outro problema, consistente na imposição de multas para os cidadãos que se recusavam a participar do conselho de jurados. Multas também aplicadas aos que designados para o conselho, não participavam das sessões. O legislador teria amesquinhado o tribunal, impondo-lhe condição repugnante, na medida em que se prescreviam multas aos faltantes nas sessões. Alencar referiase ao art. 313 do Código de Processo Criminal de 1832, que dispunha que os s Jurados, que faltassem às sessões ordinárias, ou extraordinárias, ou que tendo comparecido, se ausentassem antes de ultimadas todas as causas, seriam multados, segundo o juízo dos jurados, e por maioria absoluta de votos. 
Alencar preocupava-se além disso com o alcance do art. 321 do Código de Processo Criminal então vigente, que dispunha que não poderia exercer emprego público quem recusasse o honroso cargo de jurado, ou que fosse multado três vezes por não comparecimento às sessões de júri. Aceitava-se uma justa causa como critério de dispensa da regra, situação a ser reconhecida pelo próprio conselho de jurados. Uma lei de 3 de dezembro de 1841 havia alterado um pouco o alcance das situações de limitação de acesso a empregos públicos por não comparecimento nas sessões. Alencar, no entanto, acreditava que o instituto estava ameaçado com essas regras do código de processo criminal (ALENCAR, 1883, p. 25).

Entendia que uma reforma legislativa era necessária para que se outorgasse ao júri uma dignidade constitucional desatendida. Escreveu que se os estadistas brasileiros quisessem reabilitar o júri, deveriam pensar, o quanto antes, em restituí-lo "(...) ao seu genuíno caráter, de um direito político, tão pleno e livre, como o sufrágio" (1883, p. 27). A equiparação do júri ao sufrágio era o núcleo da argumentação de Alencar em favor indispensabilidade do conselho de jurados em matéria cível.

0 jurista literato criticava a forma complexa que se utilizava para a composição do conselho de jurados. Com esse objetivo, registrou:

"A legislação brasileira, para envolver a decisão dos jurados da maior reserva e segredo, adotou vários meios: o primeiro sorteio dos 48 jurados que devem formar o conselho geral; o segundo sorteio dos 12 jurados para formar o conselho especial de julgamento; a incomunicabilidade dos membros deste conselho, durante todo o processo, embora se prolongue, como há exemplo, cerca de 72 horas; finalmente, a votação do conselho; não só em lugar vedado, como por escrutínio secreto. Quanto fórmula vã e ridícula para alcançar o impossivel!" (ALENCAR, 1883, p. 29).

Esse método, que de resto é muito próximo do que presentemente se pratica, segundo Alencar, levantava uma permanente desconfiança em relação ao cidadão que participaria do conselho de jurados. Esse aparato, segundo Alencar, não levava em conta o fato de que o jurado também é “(..) um homem bom, compenetrado de sua alta missão, dirigido por uma consciência reta; todo esse aparato de fórmulas não serve senão para fatigar seu espírito, confundir-lhe as ideias e inabilitá-lo para proferir uma 
decisão justa (...)" (1883, p. 29). Não se considerava a singularidade do homem comum, que julgaria com justiça, na medida em que contasse com o repouso da mente e com a singeleza do bom senso.

0 júri resultava em um processo moroso e fatigante. A leitura de autos volumosos dos processos era interminável. A inquirição de testemunhas, ainda que importante, tomava muito tempo. Os debates eram inacabáveis. Segundo Alencar, eram "(...) trâmites inventados para moer o tempo e a atenção do jurado" (1883, p. 33). Os promotores e advogados esgrimiam uma retórica pouco objetiva e centrada nos ornamentos de linguagem e na predileção pelo grotesco:

"Há exemplos de oradores que atravessam uma noite a falar, e fazem timbre disso. Já se tem dado também o caso de apresentar-se o réu ladeado de três e quatro advogados; abuso que toleram os magistrados, talvez coatos pelo respeito ao direito de defesa. Por mais sagrado que seja esse direito, deve ter limite; e não ficar à discrição da parte ampliá-lo além do necessário, por mero capricho" (ALENCAR, 1883, pp. 33-34).

Alencar chamava a atenção para o fato de que um processo do júri já fora anulado porque se indicou como falta insanável o fato de que as campainhas não foram tocadas nas horas prescritas (1983, p. 34). 0 excesso de formalidades retirava a naturalidade do tribunal. No limite, para Alencar, todo cidadão votante seria implicitamente um cidadão jurado. No seu entender, votante e jurado significavam uma cidadania ativa e livre para o exercício da soberania. Competência e faculdade para o voto e a participação no júri seriam as mesmas. 0 que as diferenciava, tão somente, seria a função (ALENCAR, 1883, p. 36).

Sufrágio universal e júri universal seriam situações semelhantes, que aproximavam o cidadão votante do cidadão jurado. 0 voto e a participação no júri, segundo Alencar, eram direitos políticos inalienáveis, indicativos de manifestações da soberania nacional. 0 júri qualificava-se por ser um tribunal de fato. A parte técnica era de competência exclusiva da magistratura, a quem incumbia a dosimetria da pena. 0 jurado decidia de acordo com a consciência. Não dependia da lei, dos documentos, das testemunhas e dos peritos (ALENCAR, 1883, p. 37). 


\section{CONCLUSÕES E CONSIDERAÇõES FINAIS}

O escritor José de Alencar revela-se inesperadamente atual. Não que se discuta presentemente o papel do júri, especialmente quanto a uma retomada do modelo em matéria cível. 0 que se descortina, em seus aspectos conceituais, é uma contenda em torno dos referenciais da experiência democrática. Na medida em que Alencar aproximou o direito ao sufrágio com o direito de ser julgado por um conselho de pares, o escritor esforçava-se, nos limites de seu tempo, para enfatizar arranjos que pudessem fortalecer a relação do cidadão com os limites e alcances da soberania política. Alencar defendeu uma maior participação popular em processos decisórios de interesse de todos.

Separando o direito ativo de voto, dos direitos ativos e passivos de formação de conselhos de jurados, Alencar enfrentou o principal argumento que poderia constranger seu plano para o tribunal do júri. Tratava-se do voto censitário, que também detinha acento constitucional. Na medida em que o direito ao voto seria assemelhado ao direito de ser jurado, limitava-se, intensamente, a participação popular dos processos de decisão do júri.

Respondendo-se às duas questões inicialmente colocadas, verifica-se que a sensibilidade do escritor Alencar também se manifestou no jurista Alencar. 0 tema do júri é, na essência, um tema de sensibilidade política. Por outro lado, quanto à relação com sua obra de ficção, não se verificam pontos de convergência.

Do ponto de vista metodológico o ensaio aponta para várias possibilidades de exploração da obra jurídica de José de Alencar. Essa intersecção realça aspectos centrais no campo direito e literatura ou, a exemplo do caso presente, das relações o esforço literário e o constitucionalismo. 


\section{NOTA}

1 "Mas o fato é que, como advogado e jurisconsulto, Alencar não se limitou a ostentar um título ou ocupar uma função. Deu seguras demonstrações de conhecimentos de direito e é justamente isso o que faz lamentemos não se tenham ainda os estudiosos detido sobre essa faceta de seu espírito. As páginas que até agora foram escritas sobre Alencar como jurista são pouquíssimas." Fran Martins, José de Alencar, Jurista, Introdução aos Pareceres Jurídicos de José de Alencar, p. 22.

\section{REFERÊNCIAS}

ALENCAR, José de, A propriedade, Brasília: Senado Federal, 2004 [1883-b].

ALENCAR, José de. Esboços jurídicos, Rio de Janeiro: Garnier, 1883.

ALENCAR, José de, Pareceres, in: Obras Jurídicas Cearenses, Resgate Histórico, Fortaleza: Tribunal de Justiça do Estado do Ceará, 1960.

ALENCAR, José de. Por que sou romancista. Rio de Janeiro: Leuzinger, 1893.

ALENCAR, José de. Uma tese constitucional. Rio de Janeiro: Livraria Popular, 1867.

BOYD WHITE, James. Justice as translation, an essay in cultural and legal criticism. Chicago and London: The University of Chicago Press, 1994.

BUENO, José Antônio Pimenta, Marques de São Vicente, Direito Público Brasileiro e Análise da Constituição do Império, São Paulo: Ed. 34, 2002.

CALVO, José González. Justicia constitucional y literatura. Lima: Centro de Estudios Constitucionales, Tribunal Constitucional del Peru, 2016.

CARVALHO, José Murilo. A construção da ordem (a elite política imperial): teatro de sombras (a política imperial), Rio de Janeiro: Civilização Brasileira, 2003.

CAVALCANTI, João Barbalho Uchoa. Constituição Federal Brasileira, Brasília: Senado Federal, 1992.

DEL PRIORE, Mary. Histórias e conversas de mulher. São Paulo: Planeta, 2013. 
GARAVELLI, Bice Mortaria. Manual de retórica. Madrid: Cátedra, 2000.

LOPES, José Reinaldo de Lima. 0 oráculo de Delfos, o Conselho de Estado no Brasil Império. São Paulo: Saraiva, 2010.

LUKÁCS, Georg. A teoria do romance, São Paulo: Duas Cidades, Ed. 34, 2006. Tradução de João Marques Mariani de Macedo.

MAGALHÃES JÚNIOR, R.. José de Alencar e sua época, São Paulo: Lisa, s.d.

MERQUIOR, José Guilherme. De Anchieta a Euclides, breve história da literatura brasileira. Rio de Janeiro: José Olympio, 1977.

NETO LIRA. 0 inimigo do rei. São Paulo: Globo, 2006.

NOGUEIRA, Almeida. A academia de São Paulo, tradições e reminiscências, vol. 3. São Paulo: Saraiva, 1977.

RABELAIS, François. Gargântua e Pantagruel. Tradução de David Martins Júnior. Belo Horizonte e Rio de Janeiro: Villa Rica, 1991.

Recebido em: 31-8-2019

Aprovado em: 17-12-2019 


\section{Júlio Edstron Secundino Santos}

Doutor em Direito pelo Centro Universitário de Brasília - UNICEUB; mestre em Direito Internacional Econômico pela UCB/DF; diretor Geral do Instituto de Contas 5 de Outubro do TCE-TO Professor do IDASP/Palmas; membro dos grupos de pesquisa Núcleo de Estudos e Pesquisas Avançadas do Terceiro Setor (NEPATS) da UCB/DF, Políticas Públicas e Juspositivismo, Jusmoralismo e Justiça Política do UNICEUB; editor Executivo da REPATS E-mail: edstron@yahoo.com.br

\section{Arnaldo Sampaio de Moraes Godoy}

Livre docente em Teoria Geral do Estado pela Faculdade de Direito da Universidade de São Paulo-USP; pós-doutor em Direito Comparado na Universidade de Boston, em Direito Constitucional pela Pontifícia Universidade Católica do Rio Grande do Sul-PUC-RS, em Literatura no Departamento de Teoria Literária da Universidade de Brasília-UnB e em História do Direito na Faculdade de Direito da Universidade de Brasília-UnB; doutor e mestre em Filosofia do Direito e do Estado pela Pontifícia Universidade Católica de São Paulo-PUC-SP. MBA em Direito Comunitário Europeu pela Fundação Getúlio Vargas e pela Escola de Administração Fazendária- Brasília; professor titular do programa de pósgraduaçao em Direito do UniCeub, Brasília. E-mail: arnaldo.godoy@pgfn.gov.br Centro Universitário de Brasília. Programa de Pós-Graduação em Direito. Quadra SEPN 707/907. Asa Norte. 70790075 - Brasília, DF - Brasil 
